\title{
Corn Supply Chain Targets for Village Collector Traders (PPD) in South Sulawesi Province
}

\author{
Ilham Rasyid ${ }^{1}$, Syamsuddin Hasan'2,Dermawan Salman ${ }^{3}$,Hastang ${ }^{4}$,Sitti Nurani Sirajuddin ${ }^{4}$, Amidah $^{2}$ \\ Amrawaty ${ }^{4}, A$ hmad R Siregar ${ }^{4}$,Jasmal A Syamsu' \\ ${ }^{1}$ Agriculture Doctoral Program Student, Hasanuddin University \\ ${ }^{2}$ Department of Animal Nutrition and Food, Faculty of Animal Science, Hasanuddin University \\ ${ }^{3}$ Department of Agribusiness, Faculty of Agriculture, Hasanuddin University \\ ${ }^{4}$ Department of Social Economy, Faculty of Animal Husbandry, Hasanddin University
}

Correspondence Author: Ilham Rasyid, Agriculture Doctoral Program Student, Hasanuddin University

Received date: 28 August 2019, Accepted date: 15 November 2019, Online date: 26 November 2019

Copyright: (C) 2019 Ilham Rasyid., This is an open-access article distributed under the terms of the Creative Commons Attribution License, which permits unrestricted use, distribution, and reproduction in any medium, provided the original author and source are credited.

\begin{abstract}
This study aims to determine the target of the corn supply chain target in village collector traders in South Sulawesi Province. The time for conducting the research began in August 2018 - November 2018. For the purposes of research to measure market target and development target variables, data were collected based on survey results and interviews with 12 respondents from village collection traders (PPD), and 4 respondents who were came from the district collecting traders (PPK) as representatives of the big traders, as well as 2 people from the big traders (PB) who are domiciled in the place of business in the district capital, so that the total respondents used in the data collection were 18 people. This research uses descriptive qualitative and quantitative approaches. The types of data used in this study are quantitative and qualitative in nature by using a Likert. The results showed the target is based on market targets and development targets with an average value of 2.5 , which means that it is on a medium scale.
\end{abstract}

Keywords: supply chain, target, village collector traders

\section{INTRODUCTION}

One of the mainstay commodities of the national agricultural sector is Pipil corn which can be used for household consumption and animal feed industry needs including broilers and layers. It was further stated that because corn was a mainstay commodity, the Government of the Republic of Indonesia through the Directorate General of Food Crops provided corn seeds for farmers to be cultivated and bred for purposes other than meeting domestic needs, increasing people's income and not expecting imports anymore. This is in line with Permentan No. 57 of 2015 concerning the prohibition of imports of corn or feed ingredients of plant origin. But in reality the results of the identification of corn seed fields have not even touched the farming community

The ban on corn imports is based on the trend of the last 5 years corn production curve showed a significant increase in each successive year 2013 to 2017, namely national corn production reached 1,250,203 tons (2013) .1,490,990 tons (2014), $1,528,414$ tons (2015), 2,065,125 tons (2016), and 2,341,337 tons (2017). However, with this surplus of corn there is still a gap, namely for the poultry feed industry companies to heed the import ban and to this day still depend fully on imported corn raw materials including those from Brazil [1]

The results of the identification of field problems and data collection show that the increase in corn production is quite promising, but in reality in marketing, it often experiences constraints on the selectivity of water content, mould and wrinkles. As a result of the low quality, it greatly influences the level of prices received by large traders from the feed industry or manufacturers which also affects the price received by the collecting traders, as well as for corn farmers as the initial or upstream supply chain. This is in line with the opinion of [2] and[3], stating that with the condition of feed raw materials derived from corn produced by farmers of poor quality, it is very influential on the price received because between upstream and downstream is very interesting in terms of supply chain aspects. Therefore, to improve this condition, supply chain management and involvement of the main actors and supporting actors and business actors are needed in handling it, because if this continues it does not get attention will affect the enthusiasm of farmers in managing corn. For example, farmers as the main actors need get guidance, training and provision of technology, market transfers and assistance with corn dryers complete with the ownership of the corn storage warehouse provided by supporting actors (government) or business actors (private parties). 
When related to aspects of government programs, Corn is a strategic commodity in the development of agriculture and the Indonesian economy, considering that this commodity has a multipurpose function, both for food and feed. Exemplified the proportion of the use of corn by the feed industry in recent years has reached $50 \%$ of the total national needs. The use of corn for feed in the next 20 years is expected to increase and even after 2020 is expected to increase and can reach more than $60 \%$ of the total national needs [1]. [4] added that in Indonesia after rice, corn is a food commodity or agricultural commodity that has a strategic role in supporting livestock business. This is in line with [5] states that corn has a major contribution in the composition of feed which reaches 45 - 55 percent and plays a role in causing price fluctuations that occur in the broiler and layer sectors. Along with this phenomenon, the corn commodity affects the stability of the supply chain from upstream to downstream.

[6] stated that the role of corn in the broiler and layer sectors has increased, and has shifted its role as human consumption food. [7] stated that with the development of the poultry industry and increased rice production, the use of corn shifted from food to feed. [1] reports that this shift in the role of corn contributes a lot to the broiler and layer feed industry. It was further stated that there are 93 Feed Mills in Indonesia that utilize corn as a raw material for broiler and layer animal feed manufacturers, and the estimated need is 50 percent from national needs.

In addition to production data, domestic maize sales channel data, especially in South Sulawesi indicates dominance at a certain node that needs to be proven. The Indonesian Poultry Entrepreneurs Association (GAPPI, 2014) said that 83.3\% of farmers' corn was absorbed and bought by traders and $25.37 \%$ to the feed industry. This condition indicates the very large role of traders in distributing local corn to the corn processing industry into feed. However, in the Province of South Sulawesi, especially in the districts of Sidrap and Barru District and Makassar City, the one who played a big role was the village trader (PPD). Therefore in this study, we want to know about supply chain objectives by referring to variables; (1). Market target; and (2). Development targets carried out by village collection traders (PPD).

\section{RESEARCH METHODS}

This research was conducted in the province of South Sulawesi, with the consideration that the province of South Sulawesi is one of the corn production centres in Indonesia. For the study of the corn supply chain 4 districts were chosen, namely Gowa, Takalar, Barru, and Sidrap. The basic consideration of the 4 selected districts is the amount of corn production is quite large and is close to the broiler and layer feed industry located in Makassar. The time for conducting the research began in August 2018 November 2018. For the purposes of research to measure market target and development target variables, data were collected based on survey results and interviews with 12 respondents from village collection traders (PPD), and 4 respondents who were came from the district collecting traders (PPK) as representatives of the big traders, as well as 2 people from the big traders (PB) who are domiciled in the place of business in the district capital, so that the total respondents used in the data collection were 18 people. This research uses descriptive qualitative and quantitative approaches. The types of data used in this study are quantitative and qualitative in nature by using a Likert measurement scale[8] and[9] Data sources used are primary data and secondary data

\section{RESULT AND DISCUSSION}

\section{Supply Chain Targets for Village Collecting Traders (PPD) in terms of target markets}

To answer the target market for village traders, the indicator proposed is concerning long-term and short-term market insights and not both. Long term means the target market needs of feed mills, in this case, PT. Japfa Comfeed. Which of course has thought about the quality, quantity and continuity factors and for long-term market needs or the principle of sustainability, the village trader from the beginning should have carried out this activity in the first supply chain channel, namely the contractual agreement between the farmer and the village trader in this case, such as concerning quality, must be selective in purchasing corn from farmers who are not moldy, not rotten, particular in terms of water content. Also in terms of quantity pay attention to the ownership of storage sheds and dryers or hairdryers and use a balanced and reliable workforce. Likewise in terms of continuity, it implies market availability, also the occurrence of exchange functions, physical functions, and facility functions.

To get a picture of the target market for village traders measured from the perspective of long-term market targets, shortterm market targets, and not based on both. For more details on the results of research on supply chain channels for village traders in terms of target markets can be seen in Table 1

Table 1. Supply Chain Targets for Village Collectors in terms of Market Targets.

\begin{tabular}{|l|l|l|l|l|c|}
\hline Number & Criteria & Score & $\begin{array}{l}\text { Number of } \\
\text { Respondents }\end{array}$ & Score Number & Average \\
\hline 1 & Long term & 3 & 18 & 54 & \multirow{2}{*}{3} \\
\hline 2 & Short term & 2 & 0 & 0 & \\
\hline 3 & Not both & 1 & 0 & 0 & \\
\hline
\end{tabular}

\section{Source : research result,2018}

Table 1. Shows that the corn that has been obtained by village collectors from farmers and subsequently distributed to large traders through the extension of the district collectors' traders has been considered by village collection traders that the corn they buy will arrive at the animal feed factory through large traders, in this case disclosed by 18 respondents (100\%). And if it is assessed on a continuum as supply chain activities in terms of the target market carried out by village traders, the average score is 3.0, including the category of thinking that is advanced or high or is in the range of scores $>2.67$. Village collectors need to 
maintain this target market thinking because, taking into account the quality, quantity and continuity of the second channel; this determines the improvement of the nutritional quality of broiler and layer feed so that it can be sustained.

\section{Supply Chain Targets for Village Collectors in terms of Development Goals}

The results of the study on supply chain target variables with development target indicators based on the assessment criteria for measuring cooperation between village collectors and farmers and extension workers, as well as cooperation with extension workers or farmers, the results showed that of 18 respondents there were 0 people $(0.00 \%)$ who stated that they did not cooperate with extension agents but only cooperated with farmers, namely 18 respondents $(100 \%)$ who expressed this opinion. The reason for only cooperating with farmers is because the facilities in the form of capital to buy seeds, fertilizers, wages for cultivation purposes and post-harvest as well as the process of pemipilan and rafting, all the capital is sourced from collecting traders alone, price information, as well as knowledge about the quality of corn in obtained from diffusion through large traders that seeped into the district collecting traders which were then applied by the village collecting traders to the corn farmers. With the conditions of cooperation developed by village collector traders and farmers, there will be an understanding, mutual trust, exchange of information and knowledge. Rasyid (2018) states that if farmers are skilled and proficient and have enough information in doing farming, farmers can initiate and run farming independently, and the role of extension workers will be smaller, that is only limited to a place to consult and provide assistance. The results of research based on development objectives can be seen in table 2

Table 2. Supply Chain Targets for Village Collectors in terms of Development Targets

\begin{tabular}{|l|l|l|l|l|l|}
\hline Number & Criteria Score & $\begin{array}{l}\text { Number Of } \\
\text { Respondent }\end{array}$ & $\begin{array}{l}\text { Total } \\
\text { Score }\end{array}$ & Average \\
\hline 1 & $\begin{array}{l}\text { Cooperation between } \\
\text { extension workers and } \\
\text { farmers }\end{array}$ & 3 & 0 & 0 & \\
\cline { 1 - 5 } & $\begin{array}{l}\text { Cooperation with extension } \\
\text { workers }\end{array}$ & 2 & 18 & 36 & 2,00 \\
\hline 3 & Cooperation with farmers & 1 & 0 & 0 & \\
\hline
\end{tabular}

Source: Research results, 2018

Table 2 shows the results of a continuum analysis for supply chain target variables with development target indicators obtaining a score of 2 including the category being in cooperation or being in the range of scores 1.34 - 2.67. This cooperative relationship is not yet considered perfect because it has ignored agricultural extension workers as representatives of the government and assistants of the farming community. Therefore, farmers and village gatherers should maintain good cooperation with farmers, the reason is that if there is government assistance in the form of production inputs to farmers, as a provider of recommendations and guarantors, farmers are agricultural extension workers, as well as if farmers need capital sourced from banks then the one who gives recommendations and guarantors is agricultural extension workers. So as a recommendation in this study is that farmers and village collector traders who are also mostly from farmers must continue to cooperate with each other, and help each other and must trust each other with agricultural extension workers with the final goal in order to develop corn farming in a sustainable manner.

If the supply chain target variable value with indicators of market target and target development of maize supply is in the low category range if the results of the analysis show a score of $<1.34$ and in the medium category if the analysis results obtain a score range of $1.34-2.67$, and it is said to be a high category if the results of the analysis are at a score > 2.67. After analyzing it turns out the value achieved by the supply chain target variable with the target market indicator and the target of developing corn supply is 2.50 . This means that supply chain target variables with market target indicators and maize supply development targets are of medium category.

\section{CONCLUSION}

The value achieved by the supply chain target variable with the target market indicator and corn supply development target value is 2.50 . This means that supply chain target variables with market target indicators and maize supply development targets are of medium category.

\section{REFERENCES}

[1] Bappenas. 2005. Kajian Strategi Pengembangan Kawasan dalam Rangka Mendukung Akselerasi Peningkatan Daya Saing Daerah. Direktorat Pengembangan Kawasan Khusus dan Tertinggal - Badan Perencanaan Pembangunan Nasional. Jakarta.

[2] Hastang, Indrianty Sudirman Sitti Nurani Sirajuddin, Rahman Mappangaja, Rahim Darma.2015 Value Added Analysis of Beef Cattle Supply Chain Actors Micro-Scale Community Farm Based.AMERICAN-EURASIAN JOURNAL OF SUSTAINABLE AGRICULTURE.9(7):7-2

[3]Rasyid T.G.,Sofyan NK.,Amrulla.T. 2018.Pengetahuan Peternak Tentang Analysis Finansial Usaha Pembibitan dan Pengelolaan Pakan Ternak Berbasis Pendampingan Pelatihan.JiiP Vol.4, no.1,juni 2018.h.311-390.

[4] Napitupulu, T.E.M. 2000. Pembangunan pertanian dan pembangunan agroindustri dan pembangunan pertanian ke depan 
[5]Ilham, Nyak. 2009. Kelangkaan Produksi Daging: Indikasi dan Implikasi Kebijakannya. Pusat Analisis Sosial Ekonomi dan Kebijakan Pertanian. Bogor.bunga rampai pemikiran menuju ketahanan pangan. Editor Rudi Wibowo. Pustaka sinar harapan. Jakarta. H 57-67.

[6]Farid, M dan Maulida Lestari. 2015. Potret Jagung Indonesia: Menuju Swasembada Tahun 2017. Badan Pengkajian dan Pengembangan Kebijakan Perdagangan (Leaflet). Jakarta.

[7]Tangendjaya, B, Yusdja Y dan Ilham N. 2005. Analisis Ekonomi Permintaan Jagung Untuk Pakan dalam Ekonomi Jagung Indonesia. Badan Penelitian dan Pengembangan Pertanian, Departemen Pertanian, Bogor.

[8]Riduwan. 2013. Skala Pengukuran Variabel-Variabel Penelitian.Alfabeta, Bandung.

[9]Slamet. Y. 2011. Metode Penelitian Sosial. LPP UNS dan UNS Press Surakarta. 